\title{
CIRCULATORY MONITORING USING A CARBON DIOXIDE ANALYZER DURING PLANNED HYPOTENSION: A CLINICAL NOTE
}

\author{
R.E. Greenway, H. Heeneman, and M. KeEri-Szanto
}

Planned hypotension is a valuable adjunct to many surgical procedures. In cancer surgery of the head and neck it is expected to reduce blood loss, shorten operating time and allow a more meticulous dissection of delicate structures. There are risks associated with its use. These stem mainly from the fact that patients are rendered particularly vulnerable to blood volume changes, while the conventional indicators of adequate tissue perfusion such as heart rate, blood pressure and urine output are themselves distorted by the drugs used to induce hypotension. The technique is therefore withheld from, or only half-heartedly applied to, subjects with compromised cardiovascular status, a large group that would otherwise stand to benefit more than most from its advantages.

Carbon dioxide is the principal end-product of cell metabolism. In the anaesthetized subject most of the carbon dioxide is produced in the vital organs and is then transferred to the lungs through the bloodstream. Its appearance in the exhaled air in unchanged quantity presupposes adequate blood flow to and from the tissues producing it. Continuous monitoring of $\dot{\mathrm{V}}_{\mathrm{CO}_{2}}$ may be expected to furnish early warning of failing tissue perfusion.

During isocapnoeic ventilation ${ }^{1}$ using a Bain circuit' ${ }^{2}$ and a respiratory minute volume in the range of $4 \mathrm{l} / \mathrm{m}^{2} / \mathrm{min}$ the carbon dioxide concentration near the overflow valve is virtually unchanged during the entire respiratory cycle. Continuous sampling from this site and numerical display of the result on a Beckman LB-2 $\mathrm{CO}_{2}$ analyzer (Figure) will reflect the $\mathrm{VCO}_{2}$. Similar work was reported more than 10 years ago by one of the authors. ${ }^{3}$ Under equilibrium conditions $\dot{\mathrm{V}} \mathrm{CO}_{2}$ will equal the amount of carbon dioxide produced by the body during the same time. The equipment is sensitive enough to detect a 5 per cent change in this parameter. We have elected to treat such a change as a warning and a 10 per cent change over three minutes as a signal for action. An increase of such magnitude indicates lightening anaesthesia (preceding other signs by several minutes) while a decrease suggests deteriorating tissue perfusion and calls for slowing down the rate of hypotensive medication and/or replacing blood volume losses. Equally great or greater changes in carbon dioxide production may occur during long operations as a result of body core cooling. These proceed, however, at a much slower rate once initial heat-equilibrium has been achieved. ${ }^{4}$

A review of the experience of the otolarygology service of our hospital with this

R.E. Greenway, M.D., F.R.C.S.(C) and H. Heeneman, M.D., F.R.C.S.(C), Department of Otolaryngology, and M. Keeri-Szanto, M.D., F.R.C.P.(C), Department of Anaesthesia, Victoria Hospital, London, Ontario.

Address correspondence to M. Keeri-Szanto. Presented at the C.A.S. Annual Meeting, Montreal, 1976.

Canad. Anaesth. Soc. J., vol. 24, no. 2, March 1977 


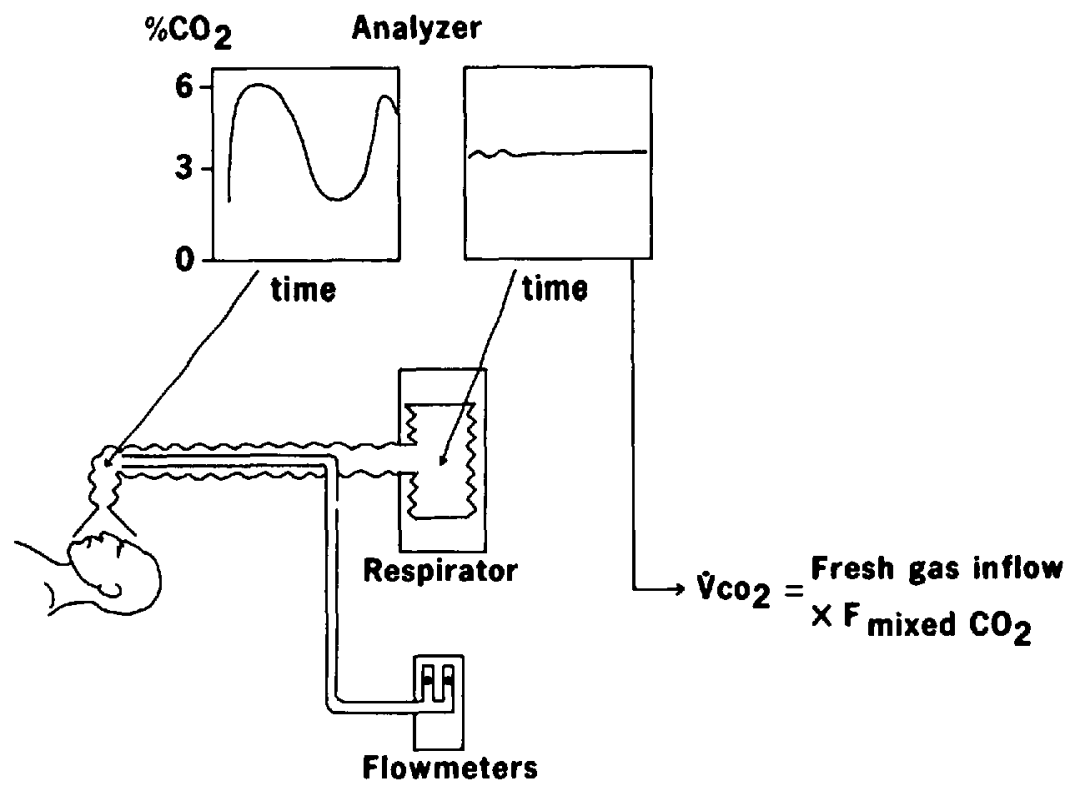

Schematic representation of $\dot{\mathrm{V}} \mathrm{CO}_{2}$ measurment during anaesthesia, using a Bain circuit and mechanical ventilation. When $\mathrm{CO}_{2}$ concentration is measured in samples originating near the mouth, changes in the course of a respiratory cycle are attenuated but still present. With sampling near the overflow valve the cyclic changes in $\mathrm{PCO}_{2}$ disappear: $\mathrm{VCO}_{2}$ then becomes the product of $\mathrm{Co}_{2}$ concentration, read from the analyzer and fresh gas inflow, read from the flowmeters. The presence of a steady state may be assumed if $\mathrm{PCO}_{2}$ readings (from the analyzer or independently from blood gases) do not change over several hours. With a fresh gas flow of $3 \mathrm{l} / \mathrm{m}^{2} / \mathrm{min}$ a .2 per cent change represents a $\dot{V}_{\mathrm{CO}_{2}}$ difference of $6 \mathrm{ml} / \mathrm{m}^{2} / \mathrm{min}$.

type of extensive surgery between mid-1974 and mid-1976 (Table) indicates that the use of planned hypotension did not shorten operating time. More time was spent under planned hypotension when this was monitored through the $\mathrm{V}_{\mathrm{CO}_{2}}$ than in the other planned hypotension group. A much larger series would be needed to decide whether or not the added dissection time benefited the patients. Blood loss was reduced in both planned hypotension series but it reached statistical significance only in the $\dot{\mathrm{V}} \mathrm{CO}_{2}$ monitored group. The average mean blood pressure during planned hypotension was virtually the same in both groups, but significantly less trimetaphan was required for this purpose in the $\dot{\mathrm{V}}_{\mathrm{CO}_{2}}$ monitored group, even though their starting mean pressure was significantly higher. The incidence of complications in such a small series is purely anecdotal, but with this reservation it supports our contention that $\dot{\mathrm{V}} \mathrm{CO}_{2}$ monitoring represents an improvement in assessing circulatory competence during planned hypotension. It should be emphasized that currently no patient of the otolaryngology service is refused the benefit of planned hypotension for reasons of reduced cardiovascular reserves, if the extent of the operation would warrant its use otherwise.

Digby Leigh pointed out nearly 20 years ago ${ }^{5}$ that a sudden fall of end tidal $\mathrm{PCO}_{2}$ is the first signal of a circulatory catastrophe. The present work is a refinement of this concept. With new equipment and with a different setup we are able to document smaller $\dot{\mathrm{V}} \mathrm{CO}_{2}$ changes sooner and to respond in a fashion that safely maintains desirable operating conditions. 
TABLE I

Effect of Planned Hypotension and $\dot{\mathrm{C}}_{\mathrm{CO}_{2}}$ Monitoring on the course of Major Maxillo-Cervico-Facial Surgery $\left(\mathrm{M} \pm \sigma_{M}\right)\left({ }^{*} p<0.01\right)$

\begin{tabular}{|c|c|c|c|}
\hline & \multirow[b]{2}{*}{ No hypotension } & \multicolumn{2}{|c|}{ Planned hypotension } \\
\hline & & No $\dot{\mathrm{V}}_{\mathrm{CO}_{2}}$ monitor & with $\dot{\mathrm{V}}_{\mathrm{CO}_{2}}$ monitor \\
\hline No. subjects & 21 & 14 & 14 \\
\hline Age, years & $64 \pm 2.2$ & $59 \pm 4.3$ & $56 \pm 2.7$ \\
\hline $\begin{array}{l}\text { Anaesthesia } \\
\text { time, hours }\end{array}$ & $4.8 \pm 0.38$ & $4.4 \pm 0.32$ & $5.3 \pm 0.45$ \\
\hline $\begin{array}{l}\text { Blood loss } \\
\text { cc hr-1 }\end{array}$ & $213 \pm 26$ & $140 \pm 31$ & $106 \pm 16^{*}$ \\
\hline $\begin{array}{l}\text { Mean B.P. torr } \\
\text { Before hypotension } \\
\text { During hypotension }\end{array}$ & & $\begin{array}{r}102 \pm 3 \\
63 \pm 2\end{array}$ & $\begin{array}{c}119 \pm 5^{*} \\
69 \pm 3\end{array}$ \\
\hline $\begin{array}{l}\text { B.P. fall } \\
\text { Per cent }\end{array}$ & & $38 \pm 2$ & $42 \pm 2$ \\
\hline $\begin{array}{l}\text { Duration planned } \\
\text { Hypotension (hrs) }\end{array}$ & & $1.9 \pm 0.2$ & $2.6 \pm 0.3$ \\
\hline $\begin{array}{l}\text { Trimetaphan } \\
\mathrm{mg} \mathrm{kg}^{-1} \mathrm{hr}^{-1}\end{array}$ & & $1.58 \pm 0.28$ & $1.04 \pm 0.19$ \\
\hline Complications & $\begin{array}{l}1 \text { Haematoma } \\
1 \text { Late death }\end{array}$ & $\begin{array}{l}2 \text { Haematomata } \\
1 \text { Nerve deafness } \\
1 \text { late CVA }\end{array}$ & $\begin{array}{l}2 \text { Confusions } \\
1 \text { Mild } \\
1 \text { Moderate }\end{array}$ \\
\hline
\end{tabular}

\section{RÉSUMÉ}

Les auteurs proposent une méthode améliorée qui surveille d'une façon continuelle la perfusion des centres vitaux. Elle est fondée sur l'hypothèse que la quantité prépondérante de $\mathrm{C}_{\mathrm{O}_{2}}$ est produite dans ces organes au cours de l'anaesthesie. Un taux constant de l'élimination de la métabolite par les poumons prouve que la succession des transferts qui lient les cellules à l'air alvéolaire n'impose pas de restrictions sur cet échange. Analysant une pèriode de deux ans dans leur service de l'ORL, 49 cas d'interventions massives furent étudiées. Les auteurs distinguent trois groupes: de patients traités sans hypotension controllée $(H C)$, ceux pour lesquels l'HC était reglée par les critères classiques (T.A., rhythme cardiaque, débit urinaire etc.) et ceux chez qui l'HC était reglée par la surveillance du $\dot{\mathrm{V}} \mathrm{CO}_{2}$. C'est seulement dans cette dernière groupe que la baisse des pertes sanguines a atteint une niveau du significance statistique. La baisse moyenne de la T.A. était presque identique dans les deux groupes soumis á l'HC mais elle fut achevée par une quantité de trimetaphan significativement réduite quand le $\mathrm{V}_{\mathrm{CO}_{2}}$ était surveillé. Dans cette série modeste qui inclut des patients porteurs d'encombrements cardiovasculaires importants, une baisse du TA moyenne de 40 pour cent durant plusieurs heures fut tolerée sans incident majeur.

\section{REFERENCES}

1. Keeri-Szanto, M. Isokapnic ventilation during surgical operations: description of equipment and first results. Anes. \& Analg. 49: 406 (1970). 
2. Bain, J.A. \& SPoerel, W.E. A streamlined anaesthetic system. Canad. Anaes. Soc. J. 19: $426(1972)$.

3. Boulangen, M., Denis, R., \& Keeri-Szanto, M. Co $\mathrm{O}_{2}$ output in anaesthetized man. Proceedings First European Congress of Anaesthesia, Vienna, p. 237-1 (1962).

4. KeERI-Szanto, M. Thermometry during surgery: an index of metabolic competence. Presented at the Canadian Anaesthetists' Society Annual Meeting, Kingston (1975).

5. Leich, M.D., Jenkns, L.C., Belton, M.K., \& Lewis, G.B. Continuous alveolar $\mathrm{Co}_{2}$ analysis as a monitor of pulmonary blood flow. Antesthesiology 18: 878 (1958). 